\title{
HUBUNGAN BRAND TRUST DENGAN KEPUASAN KONSUMEN SMARTPHONE XIAOMI REDMI 5 DI KOTA BENGKULU
}

\author{
Siti Hanila \\ Nur Fitri Wulandari \\ Fakultas Ekonomi Universitas Dehasen Bengkulu \\ st.hanila@gmail.com
}

\begin{abstract}
Brand trust is a factor that makes a company's success in consumer interest to make purchases while satisfying consumers. Satisfaction will be achieved and enjoyed if it is able to provide value relative to consumer desires. The large number of smartphone products with various brands that have sprung up in the market, has made business competition between smartphone products even tighter. The Xiaomi Redmi 5 smartphone product is one of the smartphone products that is currently quite popular among the public. To maintain the consistency of Xiaomi Redmi 5 smartphone products on the market, smartphone product manufacturer Xiaomi Redmi 5 must continue to be able to maintain consumer confidence in its products so that consumers will reflect brand reliability and brand intention from the Xiaomi Redmi 5 smartphone products it uses. The purpose of this study was to determine the relationship between brand trust and consumer satisfaction at Xiaomi Redmi 5 smartphone in Bengkulu City. This study is a correlational study with the type of data used are primary data obtained through questionnaires. The sample in this study were consumers of Xiaomi Redmi 5 smartphone products who bought smartphones in the Xiaomi City of Bengkulu Gallery totaling 39 people with the sampling method, namely accidental sampling. Data analysis methods used are analysis of average distribution, spearman rank correlation (spearman rank corellation) and hypothesis testing. The results of this study indicate that, there is a strong and significant relationship between brand trust and the satisfaction of Xiaomi Redmi 5 smartphone consumers in Bengkulu City with a correlation coefficient (correlation coefficient) of 0.799 and a probability value (sig) of $0.000<$ alpha 0.05 .
\end{abstract}

\section{Keywords: Trust Brand, Consumer Satisfaction}




\section{PENDAHULUAN}

Pada era globalisasi seperti sekarang ini, kondisi persaingan bisnis asemakin ketat yang membuat tugas seorang pemasar menjadi semakin sulit dan kompleks. Dengan adanya tuntutan konsumen yang semakin besar, mereka tidak hanya menginginkan produk yang berkualitas dengan harga yang murah, namun saat ini mereka juga menginginkan produk yang bisa meningkatkan kepuasannya. Menurut Alfansi (2012: 25), perusahaan yang sukses adalah perusahaan yang melihat bisnis dari sudut pandang konsumen, memuaskan kebutuhan konsumen dengan menyediakan produk yang relevan, dan memosisikan produk mereka di mata konsumen, relatif dibandingkan dengan produk pesaing.

Seperti yang terlihat jelas pada saat ini perusahaan yang menghadapi persaingan yang sangat ketat yaitu perusahaan teknologi informasi. Hal ini terlihat dari banyaknya produsen produk-produk telekomunikasi yang berlomba-lomba untuk memenangkan persaingan dan memiliki keunggulan kompetitif serta menjadi faktor yang mendorong munculnya sebuah gagasan atau ide-ide baru yang dapat membentuk produk ataupun jasa telekomunikasi yang dapat memberikan sebuah nilai lebih kepada para konsumennya. Pada saat ini, smartphone merupakan fenomena baru alat telekomunikasi bagi masyarakat yang memudahkan masyarakat dari segi informasi maupun berkomunikasi. Smartphone atau ponsel cerdas merupakan kombinasi dari fitur.

komputer (PDA) dan ponsel, namun lebih berfokus pada bagian ponselnya. Smartphone mampu menyimpan informasi, e-mail, dan instalasi program, seperti menggunakan mobile phone dalam satu device. Smartphone biasanya berorientasi pada fitur ponsel dibanding dengan fitur PDA. Sebagian besar perangkat mobile yang melebihi kemampuan ponsel dapat dikategorikan sebagai smartphone.

Menciptakan hubungan yang kuat dan erat dengan konsumen adalah mimpi semua pemasar dan hal ini sering menjadi kunci keberhasilan pemasar jangka panjang. Perusahaan yang ingin membentuk ikatan pelanggan yang kuat, harus memperhatikan sejumlah pertimbangan yang beragam. Kepuasan konsumen merupakan suatu keadaan dimana kebutuhan, keinginan, dan harapan konsumen dapat terpenuhi melalui produk yang dikonsumsi (Fatona, 2010: 41). Konsumen dalam memilih produk smartphone yang diinginkan adalah suatu keputusan dimana konsumen melakukan pertimbangan-pertimbangan yang disesuaikan dengan keadaan atau kondisi yang ada untuk memenuhi kepuasannya. Jika keadaan atau kondisi yang terlihat tidak sesuai dengan apa yang diharapkannya, maka akan terjadi keraguan yang dapat berakibat pada tidak puas konsumen tersebut dalam memilih produk smartphone. Hal tersebut menunjukan bahwa kepuasan konsumen sangat bergantung dengan perasaan atau kesan terhadap suatu produk/ jasa. 
Terbentuknya rasa puas konsumen terhadap suatu produk/ jasa tidak terlepas dari peran suatu merek. Merek merupakan pembeda antara produk yang satu dengan yang lain dan untuk menjamin kualitas tertentu. Merek juga sebenarnya memiliki cakupan yang lebih, merek lebih mengarah pada apa yang disebut identifikasi produk. Semakin kuat kepercayaan merek di benak konsumen maka semakin kuat pula rasa percaya diri konsumen untuk tetap setia menggunakan produk yang dibelinya. Hal tersebut terbukti bahwa merek merupakan janji penjual untuk secara konsisten memberikan feature, manfaat, dan jasa tertentu kepada pembeli (Rangkuti, 2009: 113).

Brand trust memiliki pengaruh yang sangat besar terhadap keberlangsungan sebuah merek, karena jika merek tersebut dipercayai oleh konsumen, maka produk dengan merek tersebut akan dapat terus berkembang di pasar. Kepercayaan merek merefleksikan 2 hal, yakni brand reliability atau keandalan merek yang bersumber pada keyakinan konsumen bahwa produk tersebut mampu memenuhi nilai yang dijanjikan atau dengan kata lain persepsi bahwa merek tersebut mampu memenuhi kebutuhan dan memberikan kepuasan; kemudian brand intention didasarkan pada keyakinan konsumen bahwa merek tersebut mampu mengutamakan kepentingan konsumen ketika masalah dalam konsumsi produk muncul secara tidak terduga (Ballester dan Aleman, 2004: 6).

Pada dasarnya dapat dipahami bahwa kepercayaan merek (brand trust) merupakan faktor yang membuat keberhasilan perusahaan dalam ketertarikan konsumen untuk melakukan pembelian sekaligus memuaskan konsumen. Kepuasan akan tercapai dan dinikmati jika mampu memberikan nilai relatif terhadap keinginan konsumen. Banyaknya produk-produk smartphone dengan berbagai macam merek yang bermunculan di pasar, membuat persaingan bisnis antar produk smartphone tersebut semakin ketat. Saat ini khususnya di Kota Bengkulu banyak dijumpai produkproduk smartphone dengan kualitas, model serta features yang relatif sama dapat memberikan kinerja yang berbeda di pasar karena perbedaan persepsi di benak konsumen. Demikian pula terjadi pada produk smartphone Xiaomi Redmi 5 yang merupakan salah satu produk smartphone yang saat ini cukup terkenal dikalangan masyarakat. Hal ini terlihat dari banyaknya masyarakat Kota Bengkulu yang menggunakan produk tersebut. Untuk mempertahankan konsistensi dari produkproduk smartphone Xiaomi Redmi 5 di pasaran, produsen produk smartphone Xiaomi Redmi 5 harus terus dapat menjaga kepercayaan konsumen terhadap produkproduknya sehingga konsumen akan merefleksikan brand reliability dan brand intention dari produk smartphone Xiaomi Redmi 5 yang digunakannya. Dengan adanya kepercayaan konsumen tersebut diharapkan produsen produk smartphone Xiaomi Redmi 5 akan dapat memberikan kepuasan bagi konsumennya Sejalan dengan uraian di atas mengenai pentingnya kepercayaan merek (brand trust) dalam hubungannya dengan kepuasan konsumen, maka judul yang diangkat dalam 
penelitian ini yaitu "Hubungan Brand Trust Dengan Kepuasan Konsumen Smartphone Xiaomi Redmi 5 di Kota Bengkulu

\section{TINJAUAN PUSTAKA}

\section{Pemasaran}

Pemasaran berasal dari kata pasar yaitu sebagai tempat bertemunya penjual dan pembeli untuk melakukan kegiatan transaksi. Pemasaran memiliki arti yang lebih dari sekedar proses menjual atau mempromosikan suatu produk. Pemasaran berbeda halnya dengan penjualan. Pemasaran dapat diartikan sebagai kegiatan yang mengusahakan agar produk yang dipasarkannya dapat diterima dan disenangi oleh pasar (Gitosudarmo, 2008: 14).

Menurut Kotler dan Amstrong (2012: 42) "Marketing is a social and managerial process by which individuals and organizations obtain what they need and want trough creating and exchanging value with others" Pemasaran adalah proses dimana perusahaan menciptakan nilai bagi pelanggan dan membangun hubungan yang kuat dengan pelanggan dengan tujuan untuk menangkap nilai dari pelanggan sebagai imbalannya. Sebagai ilmu, marketing merupakan ilmu pengetahuan yang obyektif, yang diperoleh dengan penggunaan instrumen-instrumen tertentu untuk mengukur kinerja dari aktifitas bisnis dalam membentuk, mengembangkan, mengarahkan pertukaran yang saling menguntungkan dalam jangka panjang antara produsen dan konsumen atau pemakai. Sebagai strategi bisnis, marketing merupakan tindakan penyesuaian suatu organisasi yang berorientasi pasar dalam menghadapi kenyataan bisnis, baik dalam lingkungan mikro maupun lingkungan makro yang terus berubah.

Alma (2011: 24) mendefinisikan pemasaran adalah aktifitas yang memfasilitasi dan mempelancar suatu hubungan pertukaran yang saling memuaskan melalui penciptaan, pendistribusian, promosi, dan penentuan harga dari barang atau jasa dan ide. Selain itu juga tergantung pada kemampuan untuk mengkombinasikan fungsifungsi tersebut agar organisasi dapat berjalan lancar. Menurut Hasan (2008: 4), pemasaran (marketing) merupakan sebuah konsep ilmu dalam strategi bisnis yang bertujuan untuk mencapai kepuasan berkelanjutan bagi stakeholder (pelanggan, karyawan, pemegang saham). Pemasaran bukanlah sekedar penjualan dan periklanan. Hal ini karena tujuan dari pemasaran adalah untuk mengidentifikasi kebutuhan pelanggan dan memenuhi kebutuhan-kebutuhan tersebut secara sangat baik. Ini berlaku dengan baik jika produk tersebut merupakan barang dan jasa, atau bahkan suatu ide. Jika seluruh pekerjaan pemasaran telah dilakukan dengan baik, pelanggan tidak perlu banyak dibujuk. Mereka akan siap untuk membeli, setelah itu, mereka akan merasa puas dan siap untuk membeli dengan cara yang sama pada kesempatan berikutnya (Cannon et al, 2008: 22). 
Dari definisi tersebut dapat diketahui bahwa proses pemasaran itu terjadi atau dimulai sebelum barang-barang diproduksi. Dibuat untuk menentukan pasar, produk, harga, distribusi dan promosi. Sehingga perusahaan harus dapat memberikan kepuasan kepada konsumen dan sebaliknya konsumen mempunyai pandangan yang baik terhadap perusahaan, produk dan jasa yang dihasilkan oleh produsen/ perusahaan. Pada dasarnya, konsep pemasaran adalah memuaskan kebutuhan pelanggan dengan memadukan kegiatan-kegatan ini dengan pemasaran untuk mencapai sasaran jangka panjang.

\section{Brand Trust (Kepercayaan Merek)}

Merek adalah nama, istilah, simbol, atau desain khusus atau adanya kombinasi unsur-unsur ini yang di rancang untuk mengidentifikasi barang dan jasa dari kelompok atau penjual tertentu (Rangkuti, 2009: 36). Menurut American Marketing Association (AMA) dalam Tjiptono dan Chandra (2012: 238) mendefinisikan merek sebagai nama, istilah, tanda, lambang, desain atau kombinasinya, yang dimaksudkan untuk mengidentifikasi barang atau jasa dari salah satu penjual atau kelompok penjual dan mendiferensiasikan mereka dari para pesaing. Pentingnya merek bagi konsumen yaitu dengan adanya merek maka akan memudahkan para konsumen untuk membedakan produk atau jasa yang dihasilkan oleh suatu perusahaan. Merek juga memberi sebuah jaminan bahwa kualitasnya tetap sama dimana pun produk tersebut didapatkan. Sedangkan bagi penjual merek memiliki peran yang penting karena memudahkan pejual untuk menawarkan produk tersebut kepada konsumen dengan menumbuhkan citra merek tersebut.

Jadi dapat dipahami bahwa merek merupakan janji penjual untuk secara konsisten memberikan tampilan, manfaat dan jasa tertentu pada konsumen. Suatu merek memberikan serangkaian janji yang di dalamnya menyangkut kepercayaan, konsistensi dan harapan. Dengan demikian, merek sangat penting baik bagi konsumen maupun produsen. Bagi konsumen, merek bermanfaat untuk jaminan akan kualitas. Sebaliknya bagi produsen, merek dapat membantu upaya-upaya untuk membangun loyalitas dan hubungan berkelanjutan dengan konsumen.

Sebuah perusahaan tentu ingin merek produk yang dimilikinya menjadi sebuah pilihan di mata konsumen, karena dengan terjadinya pembelian oleh konsumen maka akan memicu suksesnya penjualan produk tersebut di pasar. Menurut Rangkuti (2009: 37) karakteristik merek adalah sebagai berikut:

1. Nama merek harus menunjukkan manfaat dan mutu produk tersebut.

2. Nama merek harus mudah diucapkan, dikenal, dan diingat.

3. Nama merek harus mudah terbedakan, artinya harus spesifik dan khusus

4. Nama merek harus mudah diterjemahkan ke dalam berbagai bahasa asint

5. Nama merek harus bisa memperoleh hak untuk didaftarkan dan mendapat perlindungan hukum 
Suatu merek yang baik harus dapat memenuhi beberapa karakteristik tersebut, meskipun pada kenyataannya tidak semua merek tersebut dapat memenuhi karakteristik tersebut. Tetapi bagi perusahaan yang ingin memiliki keunggulan bersaing, mereka akan berusaha untuk memenuhi kriteria-kriteria tersebut agar tujuan dari penggunaan merek tersebut dapat tercapai.

Brand trust memiliki pengaruh yang sangat besar terhadap keberlangsungan sebuah merek, karena jika sebuah merek sudah tidak dipercayai lagi oleh konsumen maka produk dengan merek tersebut akan sulit untuk berkembang di pasar. Namun sebaliknya jika merek tersebut dipercayai oleh konsumen, maka produk dengan merek tersebut akan dapat terus berkembang di pasar. Kepercayaan merek adalah persepsi akan kehandalan dari sudut pandang konsumen didasarkan pada pengalaman, atau lebih pada urutan-urutan transaksi atau interaksi yang dicirikan oleh terpenuhinya harapan akan kinerja produk dan kepuasan. Kepercayaan terbangun karena adanya harapan bahwa pihak lain akan bertindak sesuai dengan kebutuhan dan keinginan konsumen.

Ballester dan Aleman (2004: 6) kepercayaan merek (brand trust) merefleksikan 2 hal, yakni brand reliability atau keandalan merek yang bersumber pada keyakinan konsumen bahwa produk tersebut mampu memenuhi nilai yang dijanjikan atau dengan kata lain persepsi bahwa merek tersebut mampu memenuhi kebutuhan dan memberikan kepuasan; kemudian brand intention didasarkan pada keyakinan konsumen bahwa merek tersebut mampu mengutamakan kepentingan konsumen ketika masalah dalam konsumsi produk muncul secara tidak terduga.

Menurut Luk dan Yip (2008: 453) brand trust mencakup niat untuk mempercayai dan memainkan peran fasilitator dalam proses pembelian. Chi et al (2009: 231) mengatakan bahwa brand trust berarti konsumen-konsumen yang percaya bahwa suatu merek spesifik akan menawarkan suatu produk yang sangat dapat diandalkan, seperti fungsi yang lengkap, jaminan kualitas dan service setelah penjualan kepada mereka. Dengan demikian dapat diketahui bahwa brand trust atau kepercayaan merek adalah suatu perilaku konsumen pada interaksinya pada suatu merek yang diharapkannya dapat diandalkan, dapat bertanggung jawab dan dapat memberikan hasil yang positif.

\section{Kepuasan Konsumen}

Kepuasan konsumen (customer satisfaction) merupakan isu yang kritikal di semua industri jasa dan perdagangan. Pengukuran kepuasan konsumen adalah sebagian dari usaha terpadu yang dapat memperbaiki kualitas produk, dan menghasilkan daya saing yang kompetitif, memicu pembelian awal, dan akhirnya dapat memberikan persepsi konsumen yang baik terhadap perusahaan. Dengan terpuaskannya keinginan dan kebutuhan para konsumen, maka hal tersebut memiliki dampak yang positif bagi perusahaan. Apabila konsumen merasa puas akan suatu 
produk tentunya konsumen tersebut akan selalu menggunakan atau mengkonsumsi produk tersebut secara terus menerus. Dengan begitu produk dari perusahaan tersebut dinyatakan laku di pasaran, sehingga perusahaan akan dapat memperoleh laba dan akhirnya perusahaan akan tetap survive atau dapat bertahan bahkan kemungkinan akan berkembang.

Kepuasan merupakan hasil dari persepsi terhadap performance nilai suatu produk atau layanan. Semakin tinggi suatu performance nilai produk yang dipersepsikan oleh konsumen maka semakin besar kemungkinan konsumen menjadi puas dan cenderung menjadi konsumen yang loyal. Pemberian pelayanan yang berkualitas kepada konsumen akan menimbulkan kepuasan konsumen. Kepuasan konsumen adalah tingkat perasaan seseorang setelah membandingkan hasil yang dirasakan dengan harapannya (Kotler dan Amstrong, 2012: 117). Pengertian tersebut menyatakan bahwa kepuasan konsumen adalah respon konsumen terhadap evaluasi ketidaksesuaian yang dirasakan antara harapan dengan loyalitas aktual produk setelah pemakaian. Jika ditinjau dari beberapa definisi kepuasan pelanggan dalam konsep pemasaran. menekankan pada evaluasi konsumen setelah pembelian. Hal tersebut sesuai pernyataan Zeithaml et al (2009: 104) yang menyatakan bahwa "customer's evaluation of a product or service in terms of whether that product or service has met the customer's needs and expectations". Dimana kepuasan konsumen adalah penilaian konsumen atas produk ataupun jasa dalam hal menilai apakah produk atau jasa tersebut telah memenuhi kebutuhan dan ekspektasi konsumen.

Kepuasan konsumen (customer satisfaction) diartikan sebagai fungsi dari seberapa sesuainya harapan pembeli produk dengan kinerja yang dipikirkan pembeli atas produk tersebut (Kotler dan Keller, 2012: 238). Pengertian kepuasan konsumen (customer satisfaction) sebagai respons emosional terhadap pengalamanpengalaman berkaitan dengan produk atau jasa tertentu yang dibeli, gerai ritel, atau bahkan pola perilaku (seperti perilaku berbelanja dan perilaku pembeli), serta pasar secara keseluruhan (Tjiptono dan Chandra, 2012: 241).

Kepuasan atau ketidakpuasan konsumen adalah respon konsumen terhadap evolusi ketidaksesuaian (disinformation) yang dirasakan antara harapan sebelumnya dan loyalitas aktual produk yang dirasakan bahwa pada persaingan yang semakin ketat ini, semakin banyak produsen yang terlibat dalam pemenuhan kebutuhan dan keinginan konsumen, sehingga hal ini menyebabkan setiap badan usaha harus menempatkan orientasi.

\section{Hubungan Brand Trust Dengan Kepuasan Konsumen}

Brand trust mencakup niat untuk mempercayai dan memainkan peran fasilitator dalam proses pembelian (Luk dan Yip, 2008: 453). Kepuasan konsumen (customer satisfaction) diartikan sebagai fungsi dari seberapa sesuainya harapan pembeli produk dengan kinerja yang dipikirkan pembeli atas produk tersebut (Kotler 
dan Keller, 2012: 238). Terbentuknya rasa puas konsumen terhadap suatu produk/ jasa tidak terlepas dari peran suatu merek. Semakin kuat kepercayaan merek di benak konsumen maka semakin kuat pula rasa percaya diri konsumen untuk tetap setia menggunakan produk yang dibelinya. Hal tersebut terbukti bahwa merek merupakan janji penjual untuk secara konsisten memberikan feature, manfaat, dan jasa tertentu kepada pembeli (Rangkuti, 2009: 113).

Membangun dan menjaga kepercayaan konsumen terhadap brand merupakan hal yang penting, karena merupakan karakteristik kunci dari suksesnya hubungan jangka panjang antara perusahaan dengan konsumen (Akbar et al, 2009: 28). Kepuasan merupakan hasil dari persepsi terhadap performance nilai suatu produk atau layanan. Kepuasan konsumen adalah tingkat perasaan seseorang setelah membandingkan hasil yang dirasakan dengan harapannya (Kotler dan Amstrong, 2012: 117). Brand trust merupakan faktor penting pada perilaku konsumen sebelum dan setelah pembelian produk, hal tersebut menyebabkan loyalitas dan memperkuat hubungan antara konsumen dan perusahaan (Liu et al, 2010: 51). Konsumen sering kali berinteraksi dengan brand seolah olah brand tersebut adalah manusia sehingga kesamaan antara konsep diri konsumen dengan brand dapat membangun kepercayaan terhadap brand (Shar, 2016: 20). Kesadaran individu terhadap brand harus dibangun secara berkelanjutan karena brand trust merupakan faktor yang membuat keberhasilan perusahaan dalam ketertarikan konsumen untuk melakukan.

\section{Kerangka Analisis}

Berdasarkan penjelasan yang telah diuraikan, maka dibuat kerangka analisis penelitian seperti gambar 1 berikut:

\begin{tabular}{|c|c|}
\hline $\begin{array}{l}\qquad \text { Brand Trust (X) } \\
\text { 1. Merek itu sendiri (Brand Characteristic) } \\
\text { 2. Perusahaan Pembuat Merek } \\
\text { (Company Characteristic) } \\
\text { 3. Konsumen (Consumer Brand } \\
\text { Characteristic) }\end{array}$ & $\begin{array}{l}\text { Kepuasan Konsumen (Y) } \\
\text { 1. Kualitas Produk } \\
\text { 2. Kualitas Pelayanan } \\
\text { 3. Emosional } \\
\text { 4. Harga } \\
\text { 5. Biaya/ Kemudahan }\end{array}$ \\
\hline
\end{tabular}

\section{Gambar 1. Kerangka Analisis Penelitian}

Kerangka analisis di atas menjelaskan bahwa brand trust (X) merupakan faktor yang berkaitan dengan kepuasan konsumen $(\mathrm{Y})$. Variabel brand trust $(\mathrm{X})$ dapat diukur melalui indikator yang meliputi merek itu sendiri (brand characteristic), perusahaan pembuat merek (company charateristic) dan konsumen (consumer brand characteristic). Serta variabel kepuasan konsumen ( $\mathrm{Y}$ ) dapat di ukur melalui lima indikator yaitu kualitas produk, kualitas pelayanan, emosional, harga, dan biaya/ kemudahan. 


\section{Metode Analisis}

Beberapa metode analisis yang digunakan untuk menjawab permasalahan penelitian ini adalah :

1. Analisis Distribusi Rata-Rata

Skala interval yang digunakan dalam penelitian ini adalah sebagai berikut :

$$
\begin{aligned}
& \text { Dik. Skor jawaban tertinggi (U) }=5 \\
& \text { Skor jawaban terendah (L) } \quad=1 \\
& \text { Jumlah kelas interval }(\mathrm{k})=5 \\
& \text { Skala Interval }=\begin{array}{cc}
5-1 & -
\end{array} \quad=\frac{4}{5} \quad=0.80
\end{aligned}
$$

Jadi jarak (skala) setiap kelas interval sebesar 0.80. Dari skala interval tersebut, selanjutnya diinterpretasikan kedalam rata-rata jawaban responden dengan kriteria:

Tabel 2.

Interval Rata-rata Persepsi Responden

\begin{tabular}{ccc}
\hline No. & Interval (Range) & Keterangan \\
\hline 1. & $1.00-1.79$ & Sangat Tidak Baik \\
\hline 2. & $1.80-2.59$ & Tidak Baik \\
\hline 3. & $2.60-3.39$ & Cukup Baik \\
\hline 4. & $3.40-4.19$ & Baik \\
\hline 5. & $4.20-5.00$ & Sangat Baik \\
\hline \multicolumn{2}{l}{ Sumber: Sugiyono (2009: 150$)$}
\end{tabular}

\section{Korelasi Rank Spearman (Spearman Rank Correlation)}

Penelitian ini menggunakan analisis kuantitatif, yaitu analisis yang digunakan untuk melakukan analisis korelasi. Metode analisis yang digunakan dalam penelitian ini dianalisis dengan menggunakan bantuan software statistik SPSS for windows, yaitu dengan menggunakan teknik spearman rank corellation. Menurut sugiyono (2009: 356), korelasi rank spearman digunakan untuk mencari hubungan atau menguji signifikan hipotesis asosiatif bila masing-masing variabel yang digunakan berbentuk ordinal dan sumber data antar variabel tidak harus sama. Adapun rumus korelasi rank spearman adalah sebagai berikut: 


$$
r_{s}=1-\frac{6 \sum d_{i}{ }^{2}}{n\left(n_{2}-1\right)}
$$

Keterangan

$$
\begin{aligned}
r_{s}= & \text { Koefisien Korelasi spearman } \\
d_{1}= & \text { Rangking data Variabel } \mathrm{X}_{\mathrm{i}}-\mathrm{Yi} \\
& \mathrm{n}=\text { Jumlah Sampel Responden }
\end{aligned}
$$

Korelasi rank spearman digunakan untuk mengetahui hubungan antara variabel brand trust $(\mathrm{X})$ dengan kepuasan konsumen $(\mathrm{Y})$. Selanjutnya untuk melihat keeratan hubungannya menggunakan pedoman interprestasi koefisien korelasi sebagai berikut:

Tabel 3

Pedoman Interprestasi Koefisien Korelasi

\begin{tabular}{ccc}
\hline No & Kategori & Tingkat Keeratan \\
\hline 1 & $0.00-0.199$ & Sangat Rendah \\
\hline 2 & $0.20-0.399$ & Rendah \\
\hline 3 & $0.40-0.599$ & Sedang \\
\hline 4 & $0.60-0.799$ & Kuat \\
\hline 5 & $0.80-1.000$ & Sangat Kuat
\end{tabular}

\section{HASIL DAN PEMBAHASAN}

\section{Hubungan Brand Trust dengan Kepuasan Konsumen}

Pengujian hubungan brand trust $(\mathrm{X})$ dengan kepuasan konsumen $(\mathrm{Y})$ digunakan analisis korelasi dengan menggunakan teknik korelasi rank spearman (spearman rank corellation). Teknik korelasi rank spearman (spearman rank corellation) digunakan untuk mengetahui hubungan brand trust dengan kepuasan konsumen dan melihat keeratan hubungannya. Guna memudakan perhitungannya, digunakan bantuan program SPSS for windows. Berikut ini disajikan hasil analisis korelasi rank spearman (spearman rank corellation) hubungan (korelasi) variabel brand trust dengan kepuasan konsumen smartphone Xiaomi Redmi 5 di Kota Bengkulu. 
Tabel 3

Tabel Korelasi

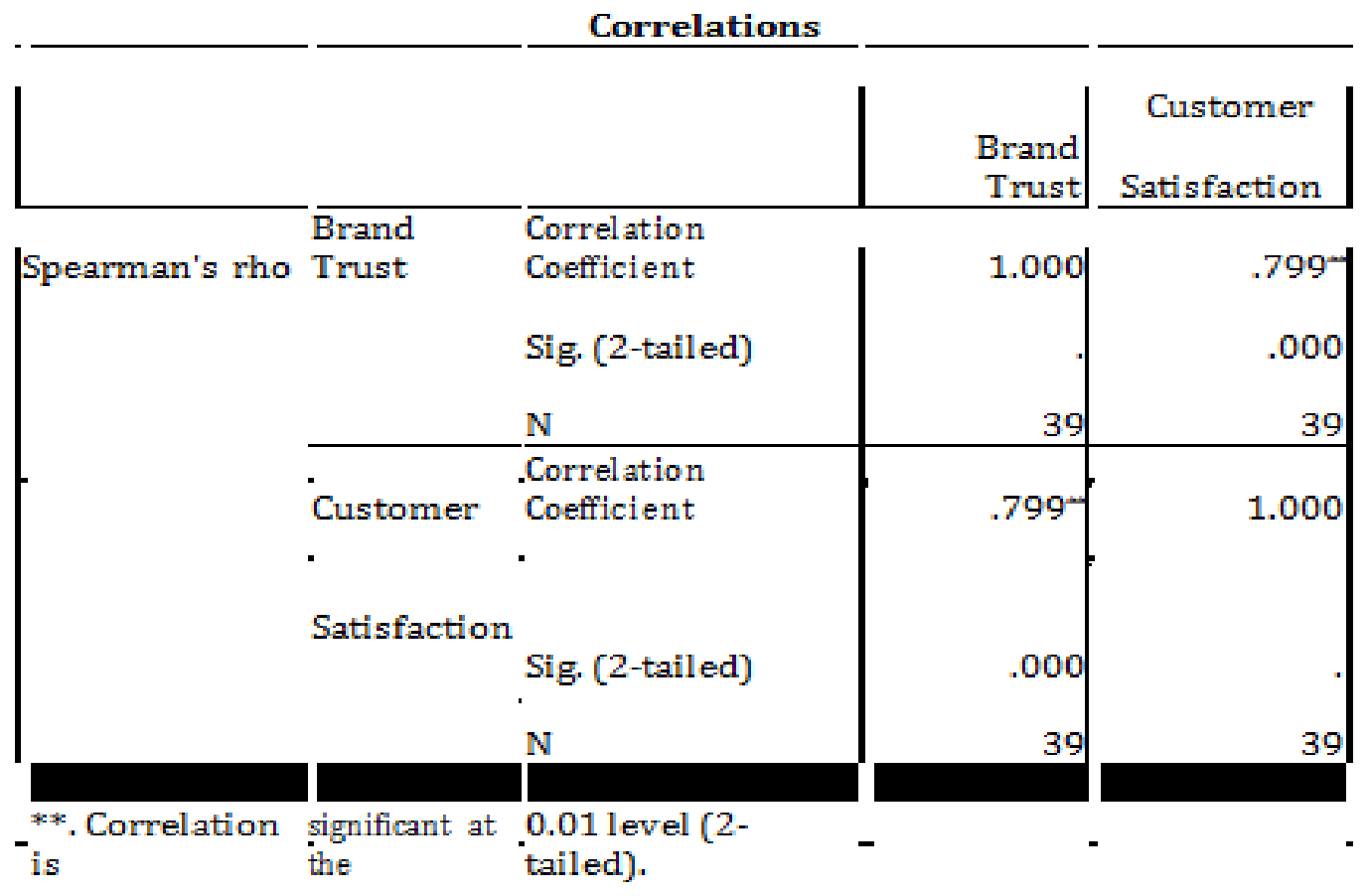

Sumber: Output SPSS for windows, Hasil Penelitian 2018

Berdasarkan Tabel 3 , diketahui bahwa correlation coefficient (koefisien korelasi) variabel brand trust sebesar 0.799 dan memiliki nilai sig. (2-tailed) 0.000 termasuk pada interprestasi koefisien korelasi 0.60 - 0.799 dengan kriteria kuat. Hal ini menunjukkan ada hubungan yang kuat dan signifikan antara brand trust dengan kepuasan konsumen smartphone Xiaomi Redmi 5 di Kota Bengkulu.

\section{Pengujian Hipotesis}

Untuk membuktikan hipotesis yang diduga sebelumnya, dilakukan pengujian hipotesis. Pengujian hipotesis dilakukan untuk menguji hubungan (korelasi) antara variabel brand trust $(\mathrm{X})$ dengan kepuasan konsumen (Y), maka dapat digunakan uji t. Guna memudakan perhitungannya, digunakan bantuan program SPSS for windows. Berikut ini disajikan hasil pengujian hipotesis hubungan (korelasi) variabel brand

\section{Pembahasan}

Menciptakan hubungan yang kuat dan erat dengan konsumen adalah mimpi semua pemasar dan hal ini sering menjadi kunci keberhasilan pemasar jangka panjang. Perusahaan yang ingin membentuk ikatan pelanggan yang kuat, harus memperhatikan sejumlah pertimbangan yang beragam. Kepuasan merupakan hasil dari persepsi terhadap performance nilai suatu produk atau layanan. Semakin tinggi suatu performance nilai produk yang dipersepsikan oleh konsumen maka semakin besar 
kemungkinan konsumen menjadi puas dan cenderung menjadi konsumen yang loyal. Kepuasan konsumen adalah tingkat perasaan seseorang setelah membandingkan hasil yang dirasakan dengan harapannya (Kotler dan Amstrong, 2012: 117). Dimana kepuasan konsumen adalah penilaian konsumen atas produk ataupun jasa dalam hal menilai apakah produk atau jasa tersebut telah memenuhi kebutuhan dan ekspektasi konsumen.

Pengertian kepuasan konsumen (customer satisfaction) sebagai respons emosional terhadap pengalaman-pengalaman berkaitan dengan produk atau jasa tertentu yang dibeli, gerai ritel, atau bahkan pola perilaku (seperti perilaku berbelanja dan perilaku pembeli), serta pasar secara keseluruhan (Tjiptono dan Chandra, 2012: 241). Kepuasan atau ketidakpuasan konsumen adalah respon konsumen terhadap evolusi ketidaksesuaian (disinformation) yang dirasakan antara harapan sebelumnya dan loyalitas aktual produk yang dirasakan bahwa pada persaingan yang semakin ketat ini, semakin banyak produsen yang terlibat dalam pemenuhan kebutuhan dan keinginan konsumen, sehingga hal ini menyebabkan setiap badan usaha harus menempatkan orientasi pada kepuasan konsumen sebagai tujuan utama (Tjiptono dan Chandra, 2012: 244). Stephen et al (2007: 6) menyebutkan bahwa outcome atau hasil yang diharapkan dari adanya kepuasan konsumen adalah peningkatan penggunaan, pembelian ulang, loyalitas dan word of mouth.

Berdasarkan hasil analisis diketahui persepsi responden yang dalam hal ini konsumen produk smartphone Xiaomi Redmi 5 di Kota Bengkulu terhadap variabel brand trust yaitu 3.78 termasuk pada interval rata-rata persepsi responden $3.40-4.19$ dengan kriteria baik. Hal ini menunjukkan bahwa produk smartphone Xiaomi Redmi 5 dapat memberikan kepercayaan bagi para konsumennya. Nilai rata-rata persepsi responden pada variabel brand trust yang tertinggi yaitu 4.28 dan 4.26 termasuk pada interval rata-rata persepsi responden 4.20 - 5.00 dengan kriteria sangat baik, hal ini menunjukkan bahwa konsumen percaya bahwa perusahaan yang memproduksi produk smartphone Xiaomi Redmi 5 memiliki reputasi dan motivasi yang baik dan konsumen merasa memiliki pengalaman yang baik dalam menggunakan produk smartphone Xiaomi Redmi 5. Sementara itu nilai rata-rata terendah yaitu 3.41 termasuk pada interval rata-rata persepsi responden 3.40 - 4.19 dengan kriteria baik, meskipun mendapatkan nilai rata-rata terendah namun responden (konsumen) tetap menyakini bahwa perusahaan yang memproduksi produk smartphone Xiaomi Redmi 5 memiliki integritas.

Serta nilai rata-rata jawaban responden yang dalam hal ini konsumen produk smartphone Xiaomi Redmi 5 di Kota Bengkulu terhadap variabel kepuasan konsumen yaitu 4.07 termasuk pada interval rata-rata persepsi responden 3.40 - 4.19 dengan kriteria baik. Hal ini menunjukkan bahwa responden (konsumen) produk smartphone Xiaomi Redmi 5 di Kota Bengkulu telah puas terhadap produk smartphone Xiaomi Redmi 5. Nilai rata-rata jawaban responden (konsumen) terhadap variabel kepuasan 
konsumen tertinggi yaitu 4.18 termasuk pada interval rata-rata persepsi responden 3.40 - 4.19 dengan kriteria baik, hal ini menunjukkan bahwa responden (konsumen) puas dengan kualitas layanan yang diberikan oleh produsen produk smartphone Xiaomi Redmi 5. Sementara itu nilai rata-rata terendah yaitu 3.90 termasuk pada interval rata-rata persepsi responden 3.40 - 4.19 dengan kriteria baik, meskipun mendapatkan nilai rata-rata terendah namun nilai tersebut masih berada pada kategori baik, ini menunjukkan bahwa responden (konsumen) puas dan yakin dengan garansi yang diberikan oleh produk smartphone Xiaomi Redmi 5.

Konsumen dalam memilih produk smartphone yang diinginkan adalah suatu keputusan dimana konsumen melakukan pertimbangan-pertimbangan yang disesuaikan dengan keadaan atau kondisi yang ada untuk memenuhi kepuasannya. Jika keadaan atau kondisi yang terlihat tidak sesuai dengan apa yang diharapkannya, maka akan terjadi keraguan yang dapat berakibat pada tidak puas konsumen tersebut dalam memilih produk smartphone. Hal tersebut menunjukan bahwa kepuasan konsumen sangat bergantung dengan perasaan atau kesan terhadap suatu produk/ jasa. Terbentuknya rasa puas konsumen terhadap suatu produk/ jasa tidak terlepas dari peran suatu merek. Merek merupakan pembeda antara produk yang satu dengan yang lain dan untuk menjamin kualitas tertentu. Merek juga sebenarnya memiliki cakupan yang lebih, merek lebih mengarah pada apa yang disebut identifikasi produk. Semakin kuat kepercayaan merek di benak konsumen maka semakin kuat pula rasa percaya diri konsumen untuk tetap setia menggunakan produk yang dibelinya. Hal tersebut terbukti bahwa merek merupakan janji penjual untuk secara konsisten memberikan feature, manfaat, dan jasa tertentu kepada pembeli (Rangkuti, 2009: 113).

Berdasarkan hasil penelitian diketahui correlation coefficient (koefisien korelasi) variabel brand trust sebesar 0.799 termasuk pada interprestasi koefisien korelasi 0.60 - 0.799 dengan kriteria kuat dan memiliki nilai probabilitas (sig) $0.000<$ alpha 0.05 termasuk pada kriteria pengujian Ha diterima dan Ho ditolak, yang berarti bahwa tedapat hubungan yang kuat dan signifikan antara brand trust dengan kepuasan konsumen smartphone Xiaomi Redmi 5 di Kota Bengkulu. Hasil penelitian ini didukung oleh penelitian Suci Fauziyah (2016) yang menyatakan bahwa variabel brand trust berpengaruh positif dan signifikan terhadap loyalitas konsumen. Serta hasil penelitian Shihab dan Sukendar (2009) juga menyatakan brand trust memiliki pengaruh yang nyata atau signifikan terhadap loyalitas konsumen.

Brand trust mencakup niat untuk mempercayai dan memainkan peran fasilitator dalam proses pembelian (Luk dan Yip, 2008: 453). Kepuasan konsumen (customer satisfaction) diartikan sebagai fungsi dari seberapa sesuainya harapan pembeli produk dengan kinerja yang dipikirkan pembeli atas produk tersebut (Kotler dan Keller, 2012: 238). Brand trust memiliki pengaruh yang sangat besar terhadap keberlangsungan sebuah merek, karena jika merek tersebut dipercayai oleh konsumen, maka produk dengan merek tersebut akan dapat terus berkembang di pasar. Kepercayaan merek 
merefleksikan 2 hal, yakni brand reliability atau keandalan merek yang bersumber pada keyakinan konsumen bahwa produk tersebut mampu memenuhi nilai yang dijanjikan atau dengan kata lain persepsi bahwa merek tersebut mampu memenuhi kebutuhan dan memberikan kepuasan; kemudian brand intention didasarkan pada keyakinan konsumen bahwa merek tersebut mampu mengutamakan kepentingan konsumen ketika masalah dalam konsumsi produk muncul secara tidak terduga (Ballester dan Aleman, 2004: 6)

Membangun dan menjaga kepercayaan konsumen terhadap brand merupakan hal yang penting, karena merupakan karakteristik kunci dari suksesnya hubungan jangka panjang antara perusahaan dengan konsumen (Akbar et al, 2009: 28). Kepuasan merupakan hasil dari persepsi terhadap performance nilai suatu produk atau layanan. Kepuasan konsumen adalah tingkat perasaan seseorang setelah membandingkan hasil yang dirasakan dengan harapannya (Kotler dan Amstrong, 2012: 117). Brand trust merupakan faktor penting pada perilaku konsumen sebelum dan setelah pembelian produk, hal tersebut menyebabkan loyalitas dan memperkuat hubungan antara konsumen dan perusahaan (Liu et al, 2010: 51). Konsumen sering kali berinteraksi dengan brand seolah olah brand tersebut adalah manusia sehingga kesamaan antara konsep diri konsumen dengan brand dapat membangun kepercayaan terhadap brand (Shar, 2016: 20). Kesadaran individu terhadap brand harus dibangun secara berkelanjutan karena brand trust merupakan faktor yang membuat keberhasilan perusahaan dalam ketertarikan konsumen untuk melakukan pembelian sekaligus memuaskan konsumen. Kepuasan akan tercapai dan dinikmati jika mampu memberikan nilai relatif terhadap keinginan konsumen. Kepuasan konsumen merupakan manifestasi dalam menggunakan produk atau layanan jasa yang diberikan oleh pihak perusahaan yang menjual produk, serta untuk tetap menjadi konsumen dari perusahaan tersebut.

\section{Kesimpulan}

Berdasarkan hasil penelitian dan pembahasan, maka dapat diambil kesimpulan yakni sebagai berikut: Terdapat hubungan yang kuat antara brand trust dengan kepuasan konsumen smartphone Xiaomi Redmi 5 di Kota Bengkulu dengan nilai correlation coefficient (koefisien korelasi) sebesar 0.799 termasuk pada interprestasi koefisien korelasi 0.60 - 0.799 dengan kriteria kuat. Terdapat hubungan yang signifikan antara brand trust dengan kepuasan konsumen smartphone Xiaomi Redmi 5 di Kota Bengkulu dengan nilai probabilitas (sig) $0.000<$ alpha 0.05 termasuk pada kriteria pengujian Ha diterima dan Ho ditolak. 


\section{Saran}

Berdasarkan hasil penelitian, maka peneliti memberikan beberapa saran yang dapat dipertimbangkan berkaitan dengan hasil penelitian yakni: Brand trust merupakan faktor yang berhubungan kuat dengan kepuasan konsumen, oleh karena itu diharapkan pihak produsen produk smartphone Xiaomi Redmi 5 di Kota Bengkulu senantiasa selalu menciptakan dan menjaga kepercayaan konsumennya seperti menjaga nama baik produk dengan terus menciptakan produk yang berkualitas dibandingkan dengan pesaing sehingga konsumen lebih tertarik lagi untuk melakukan pembelian produk smartphone Xiaomi Redmi 5. Penelitian tentang hubungan brand trust dengan kepuasan konsumen smartphone Xiaomi Redmi 5 di Kota Bengkulu ini diharapkan dapat menjadikan pertimbangan/ masukkan bagi masyarakat terutama kalangan masyarakat Kota Bengkulu untuk lebih selektif lagi dalam memilih menggunakan produk smartphone yang berkualitas dan dapat menjaga dengan baik kepercayaan konsumennya.

\section{DAFTAR PUSTAKA}

Alfansi, L. 2012. Pemasaran Jasa Finansial. Jakarta: Salemba Empat.

Alma, B. 2011. Manajemen Pemasaran dan Pemasaran Jasa. Cetakan Kesebilan, Bandung: Alfabeta.

Akbar, M. M., dan Parvez, N. 2009. Impact Of Service Quality, Trust \& Customer Satisfaction On Customer Loyalty. Abac Journal, 29(1): 24-38.

Ballester, E., dan Alemán, M. 2004. Brand Trust In Context Of Consumer Loyalty. European Journal of Marketing, 35(11/12), 1238-1258.

Cannon, J. P., William, D., Jr. Perreault., dan Jerome, M. 2008. Pemasaran Dasar-Dasar: Pendekatan Manajerial Global. Alih Bahasa: Diana Angelica dan Ria Cahyani, Buku 2. Edisi 16. Jakarta: Salemba Empat.

Chi, H. K., Yeh, H. R., dan Chiou C. Y. 2009. The Effects Of Brand Affect On Female Cosmetic Users Brand Loyalty In Taiwan. The Journal of American Academy of Business, 14(2), 230-236.

Cooper, D. R., dan Schindler, P. S. 2006. Business Research Methods. Eight Edition. New York: New Jersey Pearson Prentice Hall.

Dutka, A. 2008. AMA Hand Book for Customer Satisfaction. NTC Business Book, Illinois: Lincolnwood.

Fatona, S. 2010. Kualitas Jasa yang Mempengaruhi Loyalitas dan Relevansinya terhadap Kepuasan. Jurnal Dinamika Manajemen. Vol. 1, No.1, pp: 41-46.

Fauziyah, S. 2016. Pengaruh Brand Trust Dan Brand Equity Terhadap Loyalitas Konsumen Pada Produk Kosmetik Wardah (Survey Konsumen Pada PT. Paragon Technology And Innovation Cabang Pekanbaru). JOM FISIP Vol. 3 No. 2.

Fraenkel, J. R., dan Wellen, N. E. 2008. How to Design and Evaluate Research in Education. New York: New Jersey Pearson Prentice Hall.

Gitosudarmo, I. 2008. Manajemen Pemasaran. Yogyakarta: BPFE. 
Hasan, A. 2008. Marketing. Yogyakarta: Media Pressindo.

Kautonen, T., dan Karjaluoto, H. 2008. Trust And New Technologies: Marketing And Management On The Internet And Mobile Media. Cheltenham, Glos, UK: Edward Elgar.

Kotler, P., dan Amstrong, G. 2012. Principles Of Marketing. 13th Edition, New York: New Jersey Pearson Prentice Hall.

Kotler, P., dan Keller, K. L. 2012. Marketing Management. 14th Edition, New York: New Jersey Pearson Prentice Hall.

Liu, G., Wang, Y., dan Orgun, M. 2010. Trust Inference in Complex Trust Oriented Social Networks. Proceedings of The International Conference on Computational Science and Engineering, Aug. 29-31, IEEE Xplore Press, Vancouver, BC, pp: 996- 1001.

Luk, S. T. K., dan Yip, L. S. C. 2008. The Moderator Effect of Monetary Sales Promotion on The Relationship Between Brand Trust and Purchase Behaviour. Journal of Brand Management, Vol. 15, No. 6, pp. 452-464.

Lupiyoadi, R. 2013. Manajemen Pemasaran Jasa. Jakarta: Salemba Empat.

Putra, R. 2015. Hubungan Kualitas Produk dan Citra Merek Dengan Kepuasan Konsumen Produk Smartphone Samsung (Studi Kasus Pada Mahasiswa Fakultas Ekonomi Universitas Dehasen Bengkulu). Skripsi Fakultas Ekonomi Universitas Dehasen Bengkulu.

Rangkuti, F. 2009. The Power of Brand. Jakarta: PT. Gramedia Pustaka Utama.

Shar, A. 2016. Pengaruh Brand Image Dan Brand Trust Terhadap Customer Loyalty (Studi Pada Pelanggan Asuransi Syariah di Kota Bengkulu). Jurnal Iqtishaduna Economic Doctrine, 2 (1): 14-33.

Shihab, S. M., dan Sukendar, A. 2009. Pengaruh Brand Trust Dan Brand Equity Terhadap Loyalitas Konsumen Studi Kasus Produk Tes Widal Merek Remel. Jurnal Ilmiah Manajemen Bisnis Dan Terapan, Tahun VI No 2.

Stephen, L. S Jr., W. M, Omar., A. N, Wahid., Ismail., dan A. Harun. 2007. The Effect of Brand Image on Overall Satisfaction and Loyalty Intention In The Context of Color Cosmetic. Asian Academy of Management Journal, 12, 83-107.

Sugiyono. 2009. Statistik Untuk Penelitian. Bandung: Alfabeta.

Suharyadi., dan Purwanto, S.K. 2009. Statistika: Untuk Ekonomi dan Keuangan Modern. Edisi 2, Jakarta: Salemba Empat.

Syamsuddin dan Vismaia, S. D. 2009. Metodologi Penelitian. Bandung: PT Remaja Rosdakarya. 